\title{
Universiteit
}

Leiden

The Netherlands

\section{Not growling but smiling: New interpretations of the bared-teeth motif in the pre-Columbian Caribbean}

Samson, A.V.M.; Waller, B.M.

\section{Citation}

Samson, A. V. M., \& Waller, B. M. (2010). Not growling but smiling: New interpretations of the bared-teeth motif in the pre-Columbian Caribbean. Current Anthropology, 51(3), 425-433. Retrieved from https://hdl.handle.net/1887/16570

Version: $\quad$ Not Applicable (or Unknown)

License: $\quad$ Leiden University Non-exclusive license

Downloaded from: https://hdl.handle.net/1887/16570

Note: To cite this publication please use the final published version (if applicable). 


\section{Reports}

\section{Not Growling but Smiling: New Interpretations of the Bared-Teeth Motif in the Pre-Columbian Caribbean}

\section{Alice V. M. Samson and Bridget M. Waller}

Faculty of Archaeology, Leiden University, Postbus 9515, 2300 RA Leiden, The Netherlands (a.v.m.samson@arch .leidenuniv.nl)/Centre for the Study of Emotion, Department of Psychology, University of Portsmouth, Portsmouth PO1 2DY, United Kingdom. 18 XI 08

Insights into the character of social relations are rare but exciting glimpses when it comes to archaeological populations. This paper uses a multidisciplinary combination of archaeological and evolutionary biological approaches to assess the social value of the bared-teeth motif (BTM) in preColumbian iconography of the Greater Antilles. Bared teeth feature on discrete artifact categories within the material culture of many different groups in the Taíno culture area after AD 1000. This BTM, usually part of facial anthropomorphic or zoomorphic decoration, is used for bodily adornments and items associated with healing and shamanic practices. It has generally been interpreted as representative of death, aggression, or the shamanic trance. However, the motif has never been examined in terms of its signal value as a positive facial expression. Studies of facial expression in human and nonhuman primates have shown that the bared-teeth expression is used in social contexts as an unambiguous signal of nonaggression, affiliation, and benign intent. This expression could likewise have functioned in the pre-Columbian Caribbean as a communicative signal in complex social interactions in both human and nonhuman (spirit, animal, natural) worlds and may have been essential for the maintenance of cohesive and stable inter- and intracommunity relationships.

The human face carries a wealth of social information and, as such, is one of the most salient, attention-grabbing visual elements within our social environment. Representations of faces abounded in the material world of the pre-Columbian inhabitants of the Greater Antilles (AD 1000-1600): often human or animal but more commonly a composite of both. These faces appear as decorative additions to pottery and

(C) 2010 by The Wenner-Gren Foundation for Anthropological Research. All rights reserved. 0011-3204/2010/5103-0009\$10.00. DOI: 10.1086/ 651090 domestic utensils, on bodily and clothing adornments, on ritual and shamanic paraphernalia, and in rock art. One of the most arresting motifs in this iconographic repertoire is the bared-teeth motif (BTM), which is used for the mouth on certain artifacts (see figs. 1-5). This motif has been little discussed in the literature, and where it has, it is usually characterized as representing a death mask. In the rare occasions that it has been considered representative of a facial expression, it is regarded as one of diabolical ferocity or the grimace of a shaman in a state of trance. These interpretations, however, either are too narrow for the range of contexts in which the motif appears or are at odds with theories in the psychological and evolutionary literature relating to the meaning of similar facial expressions in extant human and nonhuman primate populations. The BTM shares physical and contextual similarity with the human and nonhuman primate bared-teeth display ([BT] or smile; see fig. 7), and we suggest that it likewise functioned as a cooperative social signal. An interdisciplinary perspective proposes new directions for the interpretation of facial expression in indigenous material culture that have significant repercussions for understanding social interaction.

\section{The Occurrence of the Bared-Teeth Motif}

The BTM consists of a horizontal incised line crossed by shorter vertical hatches and appears on a variety of artifacts of wood, shell, stone, bone, or cotton and often as an inlay (usually shell). Among the diverse peoples who inhabited the Greater Antilles, henceforth referred to as Taínos, ${ }^{1}$ the BTM is a prominent and seemingly important characteristic of material culture, seldom occurring before AD 1000 but persisting into the Euro-American Contact and Postcontact periods. ${ }^{2}$ The expressive message of the motif was so important that it was even incongruously incorporated in otherwise animal features such as bird beaks (see fig. 1 in this article and numerous bird pendants in Dacal Moure and Rivero de la Calle 1996). Apart from being recognized as one of the hallmarks of preColumbian iconography, this innovation in the Greater An-

1. "Taíno" is used here as shorthand for people with shared aspects of material culture in Cuba, Jamaica, the Bahamas, Hispaniola (Haiti and the Dominican Republic), Puerto Rico, and some of the northern Lesser Antilles in the 500 years preceding and including the Contact Period. However, the term encompasses a wide synchronic and diachronic range of sociopolitical, linguistic, and cultural affiliations (see Curet 2003).

2. The morphology, context, and meaning of the bared-teeth motif is different in the Lesser Antilles and on the South American mainland, where it also appears in material culture (see Boomert 2000; see also depictions of the jaguar with displayed teeth among the NhamundáTrombetas of the lower Amazon; A. Boomert, personal communication). Here it occurs almost exclusively in conjunction with depictions of animal figures (dogs, jaguars, serpents_-symbols from the mainland), as an animal trait and desired animal characteristic of the shamanic alter ego. Its occurrence in archaeological contexts in the Lesser Antilles may be attributed to imitation or exchange with groups in the Greater Antilles (Hofman et al. 2008). 


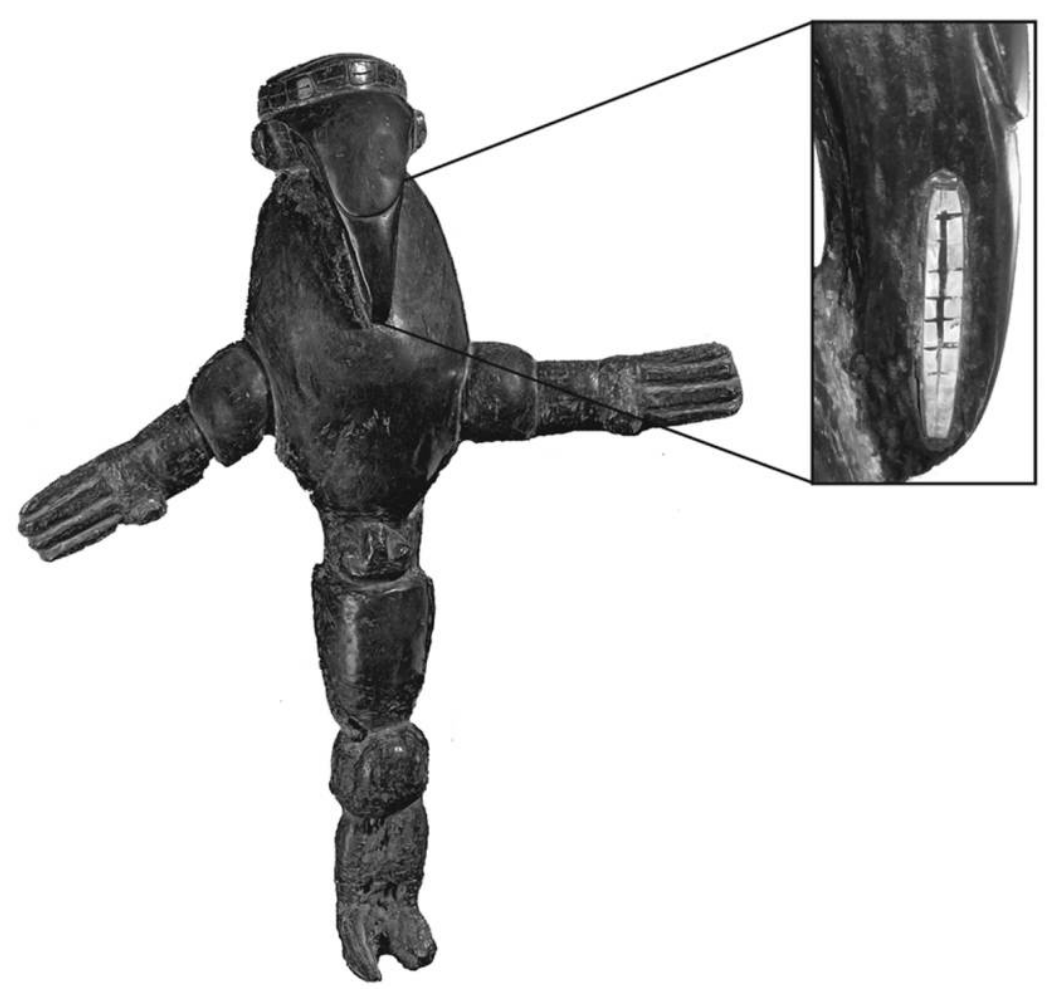

Figure 1. Bird-headed figure, Jamaica. Wood with shell teeth inlay (88 $\mathrm{cm})$; the British Museum. Photo courtesy Trustees of the British Museum and authors.

tillean repertoire has not, to our knowledge, been the subject of much attention (which is mainly focused on the eyes and ears). An exception is an article on anthropomorphic carvings from the Greater Antilles by the Puerto Rican scholar De Hostos (1923:543), who dedicated a page to representations of mouths, remarking that at least $95 \%$ of the stone carvings known to him had open mouths and that "the size of no other feature was so exaggerated as that of the mouth." $\mathrm{He}$ depicts more than 100 sketches of mouths occurring mainly on stone artifacts. Only about one-fifth of these have any indication of teeth, although, as he remarks (De Hostos 1923: 541), the likelihood is that where the mouth appears as a shallow depression, it would have contained an inlay of shell or another material depicting the teeth (as would have been the case for the artifacts in figs. $4,5 B, 5 C$ ). This is witnessed from the many archaeological finds of such inlay pieces and the artifacts that still retain these incrustations (Alegría 1981; Jardines and Calvera Rosés 1997; Lovén 1935; Rives Pantoja 1991; Valcárcel Rojas 1999).

Artifacts presumed to be body adornments (such as necklaces, armbands, belts, and forehead pieces) are also often decorated with the BTM. These are generally conch shell artifacts with single or multiple perforations for attachment, such as pendants and small faces (guaízas; see fig. 2), but also Oliva spp. shells with incised faces and bared teeth (see fig.
3). A number of small stone pendants also represent a typical Taíno posture of a crouched human figure with large ears and ear pendants, pronounced eyes, and bared teeth (see, e.g., Dacal Moure and Rivero de la Calle 1996; Fundació Caixa de Girona 2006; Fundación Centro Cultural Altos de Chavón 1992; Kerchache 1994). Occasionally, sniffing tubes (for hallucinogens) and vomiting spatulas (for purification) were decorated with anthropozoomorphic figures with the incised bared-teeth design (see fig. 4). Larger composite artifacts with faces displaying bared-teeth inlays include wooden stools (referred to as duhos), carved wood figures, three pointers, and cohoba stands (figs. 1, 5). ${ }^{3}$

Although all the items described above occur in varying social contexts, some distinct categories can be distilled. The

3. Three pointers; pyramidal-shaped objects of stone, baked clay, or coral in various sizes and states of elaboration are some of the most enigmatic artifacts in Caribbean archaeology and were in use for more than 1,000 years over the entire island Caribbean. In the Taíno period these have been classed as a type of zemi, or embodiment of ancestral spirit, often associated with fertility (of people and crops). Cohoba stands are usually wooden platforms supported by an anthropozoomorphic figure for the inhalation or blowing (into the nostrils of another person) of hallucinogens (cohoba) or stands for food offerings. The cohoba ritual involved cycles of fasting and vomitory purification (Boomert 2000: 449-454). 


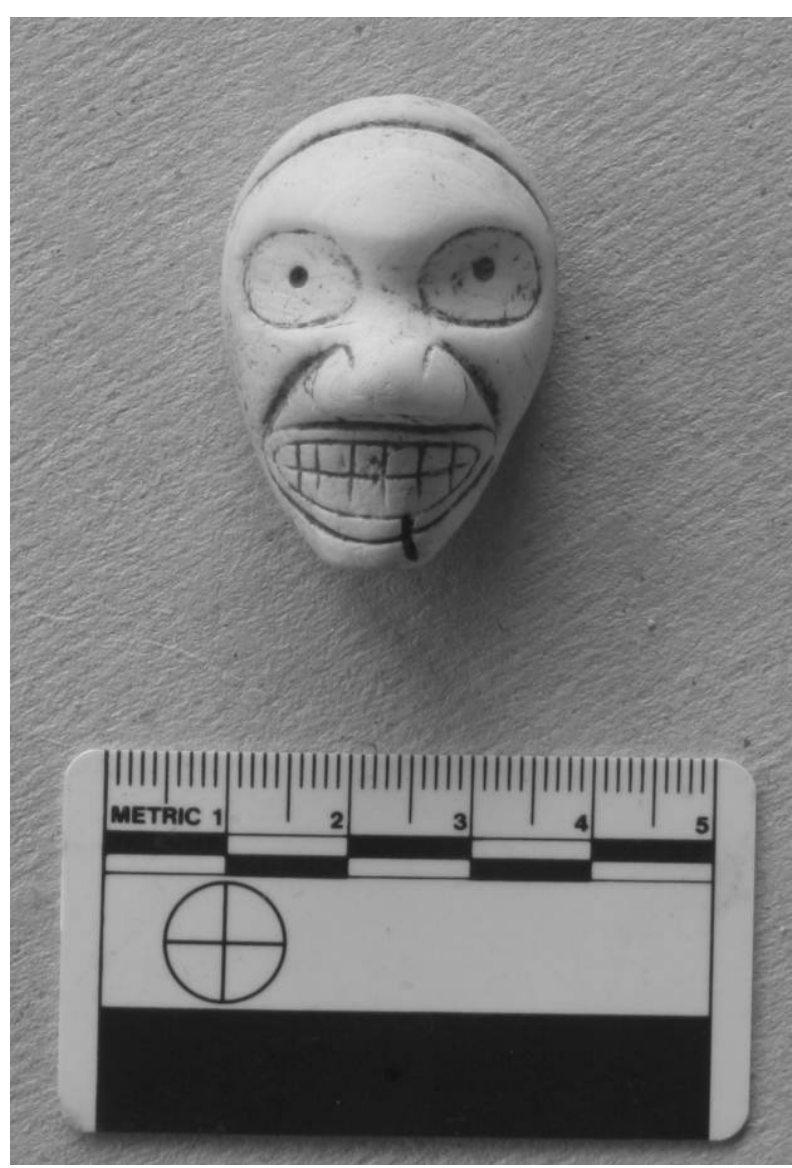

Figure 2. Shell (strombus) face, Dominican Republic. From the site of El Cabo, Altagracia; Museo del Hombre Dominicano. Photograph by Menno L. P. Hoogland.

BTM was used on items associated with shamanic activities and the cohoba ceremony (the sniffing pipes, wooden stands, wooden stools, and vomiting spatulas), as well as on bodily adornments. In contrast, very few ceramic vessels carry the BTM, despite the fact that a significant proportion of domestic serving and cooking vessels abounded with detailed adornos (modeled appendages, often in the form of a face or faces) depicting a carnival of anthropozoomorphic characters. ${ }^{4}$ Many vessels have at least two (and up to six) faces, and it would have been a simple matter to incise teeth in wet or leather-hard clay. Instead, it is the eyes, nose, and ears that are emphasized, with the mouth relegated to a transverse furrow low in the face or missing altogether (see fig. 6; see, e.g., Herrera Fritot and Youmans 1946; Krieger 1931). This absence can be noted across the range of ceramic styles within the islands of the Greater Antilles. In rock art, the teeth on

4. Some exceptions are the cephalomorphic ceramic vessel in col. Garcia Arevalo, inv. 2265 (Fundació Caixa de Girona 2006, fig. 67); a ceramic sherd from the site of En Bas Saline, Haiti (Deagan 1988, fig. 4); an adorno from San Juan midden (Krieger 1931, pl. 15); and the head of a ceramic figurine from Sitio Aguas Gordas, Holguín, Cuba (Valcárcel Rojas 2000, fig. 12). human-animal figures are also very seldom displayed. ${ }^{5}$ Thus, the BTM is mobilized deliberately and meaningfully in specific contexts. We address the possible meanings below.

\section{Formative Interpretations: The Devil,} the Trance, and the Dead

One source of information as to the meaning of the BTM comes from early Spanish texts. When Columbus made his first journeys to the Bahamas, Cuba, and Hispaniola at the turn of the fifteenth century, several early witnesses recorded their impressions and interpretations of the habits and beliefs of the natives and also included vivid descriptions of their material world. These texts provided the first accounts of European-American encounters and therefore invented a New World for European consumption (Rabasa 1993).

These early reports bear descriptions of items that probably included the BTM, and this is where the "devil" grimace was first referred to. Take, for example, this passage on images of

5. Some exceptions are petroglyphs at MC-5 Cuckold Point in Jamaica (Lee 2006); Cueva de Santa Rita, Holguín, Cuba (Guarch Rodríguez and de Rosario Pérez Iglesias 1994, fig. 2); Cueva de las Mercedes, Sierra de Cubitas, Camaguey, Cuba (Gutiérrez Calvache 2002:23); and Cueva de Ferrocarril Los Haitises, Dominican Republic (Vega 1987:64).

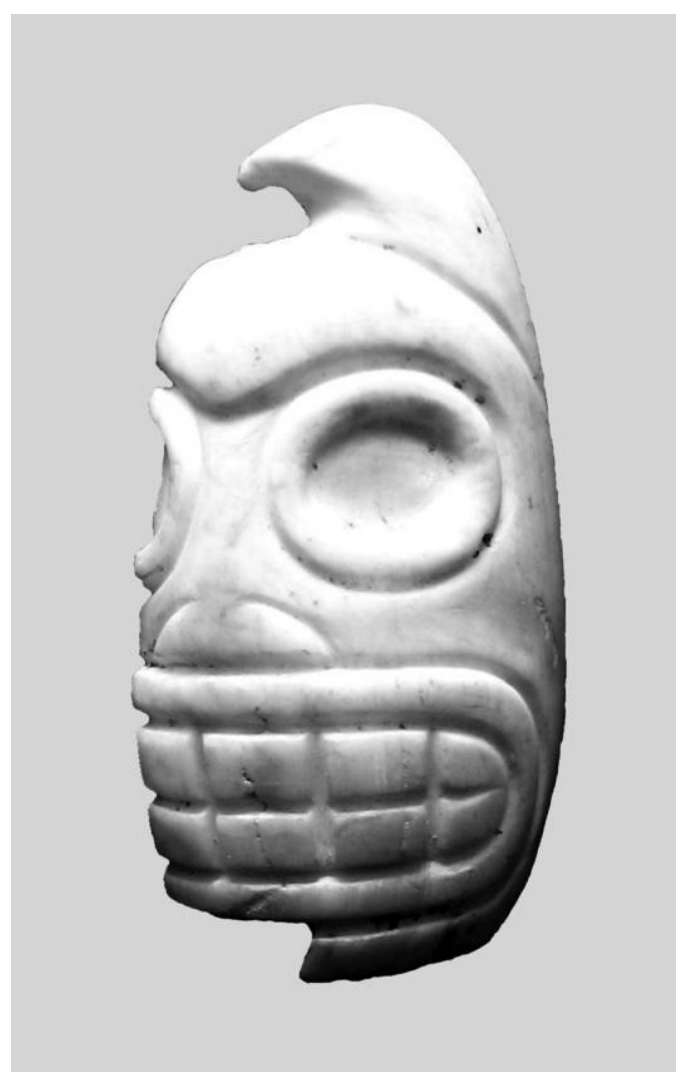

Figure 3. Shell (Oliva sp.) bead, Cuba. Possibly used strung in bundles around calves, ankles, or upper arms; Museo Provincial de Holguín. Photograph by Angus Mol. 


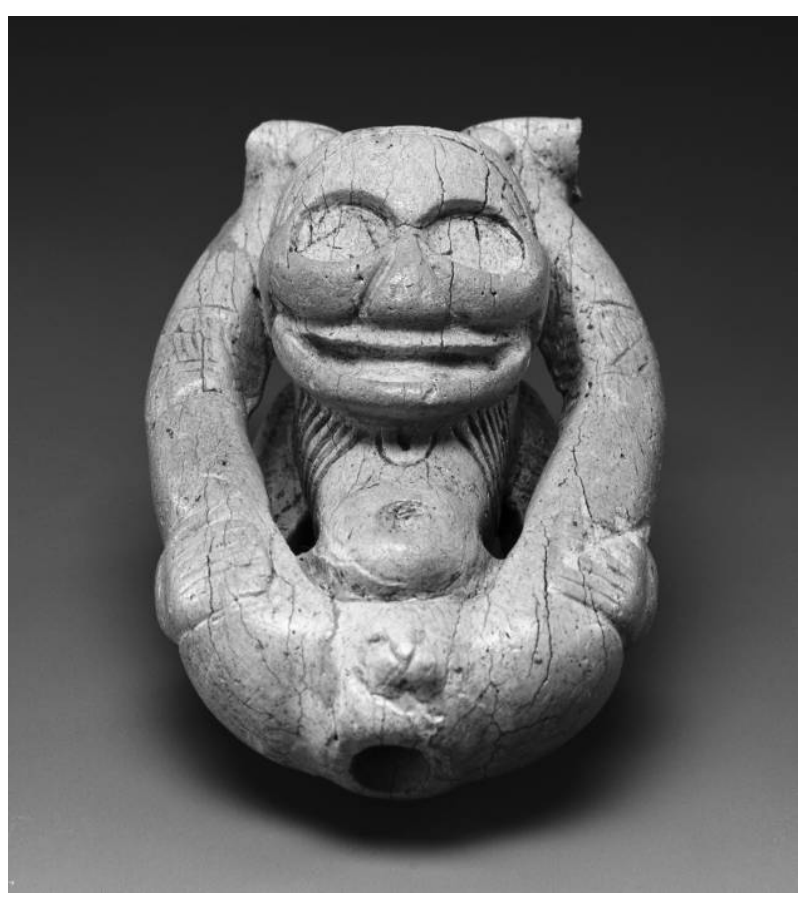

Figure 4. Sniffing tube, Dominican Republic. Manatee bone (9 $\mathrm{cm}$ ); Fundación García Arévalo, Santo Domingo. Photograph by Dirk Bakker.

the native zemi figures (interpreted as heathen deities) from Fernández de Oviedo y Valdez (1851), who spent time in Hispaniola in the first half of the sixteenth century. He describes the zemis of the Indians as representing an abominable figure, executed in many different ways and from different materials, deformed and frightening with ferocious fangs and teeth and disproportionate ears and burning eyes of a dragon that provoked much fear and admiration (paraphrased from Fernández de Oviedo y Valdez 1851:125). These early interpretations clearly inspire subsequent interpretations. For example, later descriptions of the "typical" facial expression of zemi figures, with open mouths and sunken eyes, are couched in terms similar to the those of the sixteenth century, as diabolical and associated with ferocity or aggression or the expression of malevolent deities who need to be appeased (see Cassá 1974:99; Vega 1987:25). Additional problems are encountered for artifacts that have lost teeth inlays, such as many three-pointed stones, described as having expressions of grief or rage (Cassá 1974; Vega 1987:26). In all these cases, it is the Christian political discourse of the early chroniclers that filters into contemporary interpretations of indigenous life. Thus, the interpretation of the facial expression is based on historical, Eurocentric precedent and not an understanding of the social context in which it was used.

In another interpretation, the BTM is seen as the exposed teeth of a skull. This is part of a suite of traits, such as exposed ribs and shoulder blades, representing skeletal elements (although representations with bared teeth can have fleshy faces, full noses, and lips and cheek musculature; see the detail of the face in fig. 2). Hence, these faces have been discussed as a death mask or skull or a putrefying visage of an ancestor figure (Arrom 1989:55-56; Garcia Arévalo 1997:112-114; Vega 1987). Although the BTM may recall or, indeed, reference a skull, this should not necessarily be seen as a synecdoche for the whole corpse or death per se. Death for the Taíno, and in Amerindian religion today, was not conceptualized as the antithesis of life, as it is in Western epistemology. For example, in Taíno mythology, the dead occupied a nonexclusive nighttime world parallel to that of the living and were almost identical in physical appearance (Pané 1999: 18-19). Likewise, the figure of the living shaman, as portrayed through ceramic and other representations, embodied elements of death and life, mortality, and fecundity (Boomert 2000; García Arévalo 1997; Roe 1997; Vega 1987). In contrast, in the Eurocentric interpretation of death imagery, the skull does symbolize death.

Finally, there appears to be an implicit consensus that the BTM represents the face of the shaman in trance, the transformative stage of a shaman's journey, teeth clenched in druginduced concentration or spasm (Mol 2007:133; J. Mans and A. Boomert, personal communication). We emphasize implicitness because of the lack of published material.

The polyvalent character of Taíno imagery means that we do not need to reject all these possible interpretations in order to suggest another. The reference to skeletal elements and the face of a shaman in trance may well have been important aspects of the motif. However, if the BTM additionally represented a facial expression, we argue that it was far from diabolical.

\section{New Interpretation: A Signal of Affiliation and Benign Intent}

If the BTM represents a facial expression, it does not, as previously suggested, bear similarity to the universal human facial expressions associated with aggression. Exposed and clenched teeth are not common features of the universal facial expression of anger, which is instead characterized by widened eyes, tensed lower eyelids, and lowered, furrowed brows (Ekman, Friesen, and Hager 2002). When the mouth does feature as a salient part of an anger expression, the lips are pressed and cover the teeth, or the upper lip is slightly raised and upper teeth are exposed minimally. Also, in three of the seven prototypical variants of anger expressions, the jaw is dropped rather than clenched. In fact, the only prototypical human facial expression where the teeth are commonly exposed and the jaw is not dropped is the smile. Unlike the caricatured upturned curve often used as shorthand, the BTM is a more faithful rendering of the human smile. In the smile, the lip corners are much less upturned than sometimes perceived (Waller et al. 2007).

That the smile (morphologically speaking) is the best comparison to the BTM is not to say that it necessarily reflects positive emotion. Although smiling is often considered a facial 


\section{A}

A
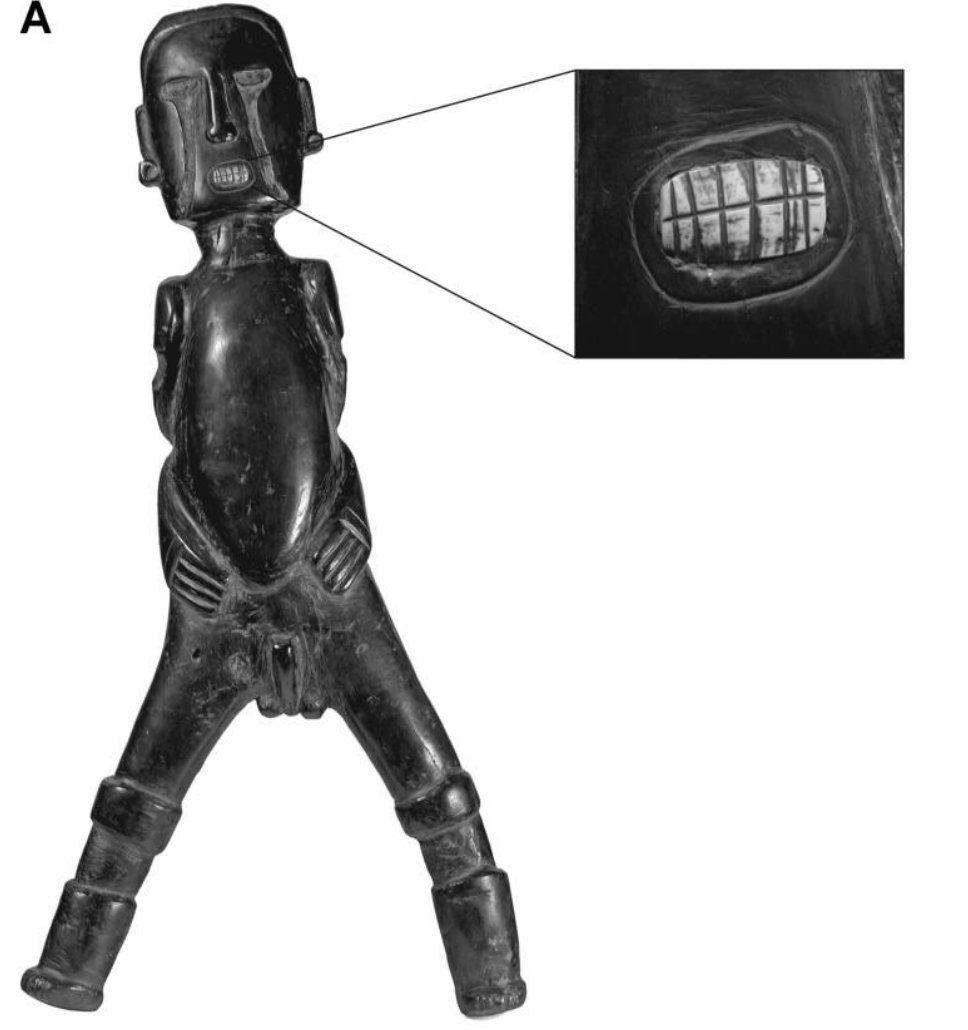
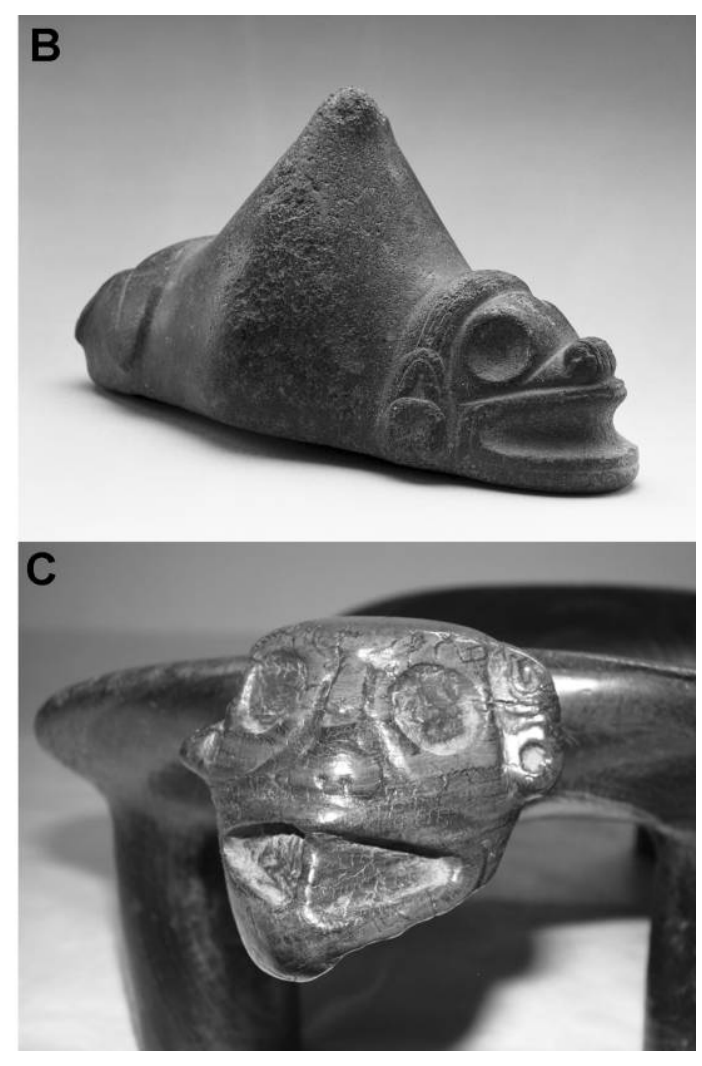

Figure 5. A, Standing figure, Jamaica. Wood with shell teeth inlay (100 $\mathrm{cm})$; the British Museum. Photo courtesy the Trustees of the British Museum and authors. B, Three pointer, Puerto Rico. Stone $(10 \times 21$ $\mathrm{cm}$ ); Museo de la Universidad de Puerto Rico. Photograph by Dirk Bakker. C, Duho (stool), the Bahamas. Wood; the British Museum. Photograph by the authors.

expression of positive emotion, most commonly happiness, this can be a misleading interpretation. Fridlund (1994) argued that facial expressions should be considered as communicative signals and their meaning interpreted not by the felt emotion of the sender (which may function simply as a mechanism for production) but by the role they play in social interaction. Likewise, Mehu, Grammer, and Dunbar (2007) demonstrated that smiling in humans facilitates cooperation and sharing and thus concluded that smiling aids the bonding of social groups - an attribute that was likely very important in the evolution of primate society. Importantly, Mehu, Grammer, and Dunbar (2007) showed that the felt emotion of the individual displaying the smile did not affect frequency of smiling. Therefore, although the frequency of smiling affected the likelihood of cooperation, this was not necessarily reliant on how the sender was feeling. Thus, although emotion is intuitively associated with facial expressions, the coupling of the signal (the expression) and the experience (the emotion) may sometimes hinder our understanding of how the smile is actually used in human society. Hence, we need to make comparisons between smiling and the motif not as expressions of emotion but as communicative signals.

Our understanding of the social function of the human smile has increased enormously in light of comparative data from other primate species. The bared-teeth display (BT) is common to most social primates and has been proposed as an anatomical and functional homologue to the human smile (van Hooff 1972; Waller et al. 2006). Even though it can occur within different contexts for different species, this seems to be related to power asymmetry within the species (Preuschoft 1995). In primate species with a strict dominance hierarchy, such as rhesus macaques (Macaca mulatta), BT (see fig. 7C) is used by subordinate individuals when interacting with dominants and is a signal of submission (de Waal and Luttrell 1985). In contrast, in primate species with more flexible hierarchies, such as chimpanzees (Pan troglodytes), BT (see fig. $7 B$ ) is produced in many different contexts (Parr, Cohen, and de Waal 2005), but all seem to be characterized by some level of uncertainty.

Nevertheless, regardless of the specific context, the function 


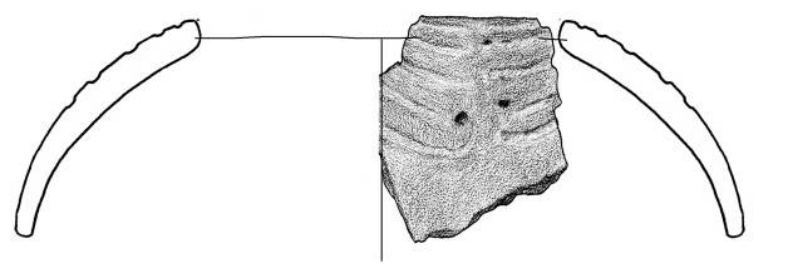

1
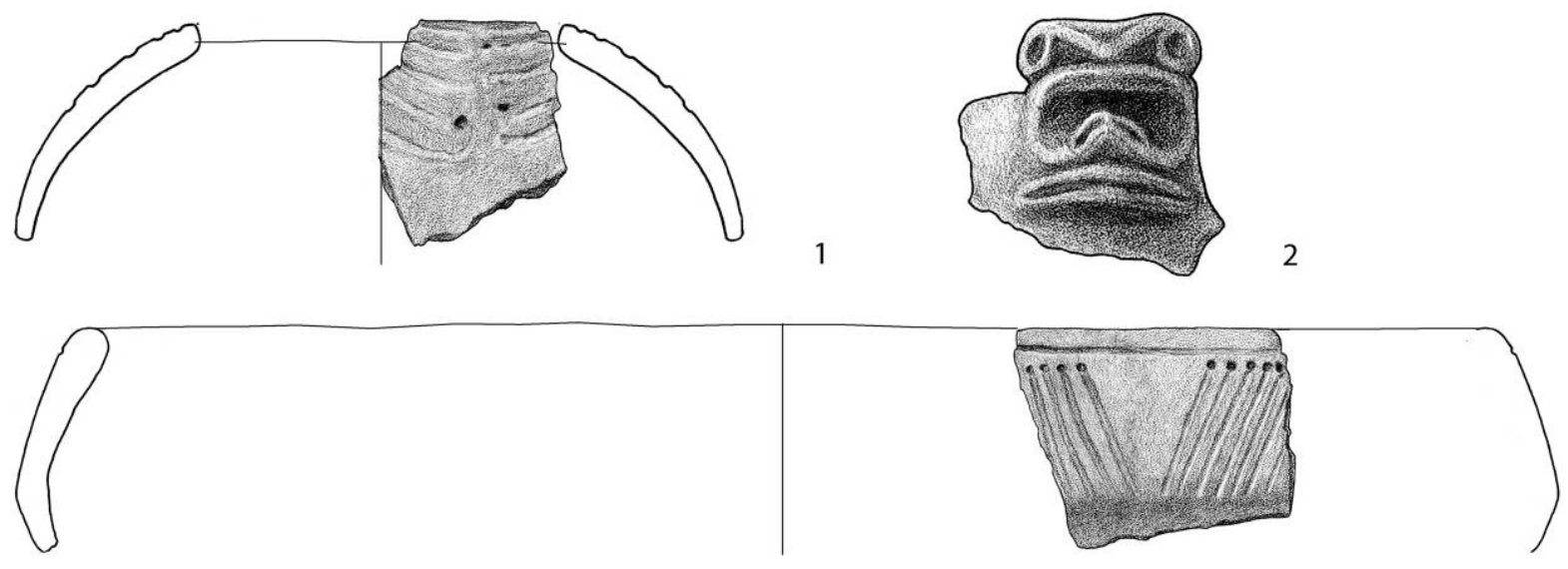

3
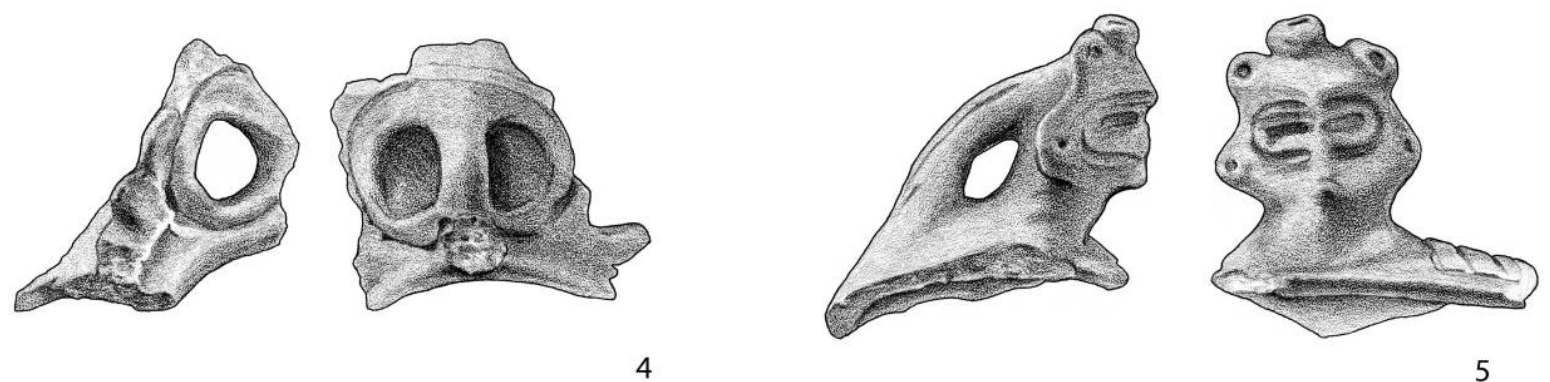

4

5

Figure 6. Ceramic adornos from the site of El Cabo, Dominican Republic.

Illustrations by Medy Oberendorff.

(in terms of the resulting behavioral outcome) is similar. Waller and Dunbar (2005) showed that regardless of behavioral context, the BT was followed by an increase in affinitive behavior in chimpanzees, thus exhibiting a social bonding function. In essence, therefore, the BT increases social proximity (by avoiding conflict in hierarchical species or increasing affinitive social interaction in flexibly organized species). What exemplifies the meaning of this display in all primate species (including humans) is benign intent (the antithesis of aggression; sensu Silk 2000; Waller and Dunbar 2005). So, the $\mathrm{BT}$ is not aggressive and has a clear affiliative and/or appeasing function in nonhuman primates (regardless of emotional correlates). Thus, the primate BT (and human smile) is best interpreted as a signal of benign intent that functions to increase social proximity. This interpretation fits well with conceptualizing the human smile as a signal of acceptance (Frijda 2009) and, similarly, the BTM as a signal of benevolence and nonaggression.

\section{The Utility of the Bared-Teeth Motif in Taíno Social Life}

It is notoriously difficult to reconstruct the character of social relations on the basis of the three main sources available to researchers, namely, several early Spanish texts, archaeological data from excavations and collections, and ethnographic anal- ogy with the indigenous peoples of the South American mainland. Nevertheless, archaeology, the study and contextualization of the material world of past human populations, provides the most direct and reliable source of information on indigenous life. As such, the prevalence of the BTM in material culture informs us on a dominant strategy in Taíno social interaction: communication, benignity, and social proximity.

The culture of the Greater Antilles lacks homogeneity. In fact, it may be precisely this lack of homogeneity that is the characteristic feature of the population. From around AD 600, there is a trend to population growth and cultural hybridization that intensifies in the ensuing centuries. Significant intercommunity differences are seen in terms of language use, group affiliation, settlement and mortuary variability, and forms of sociopolitical organization (Curet 2003, 2005; Delpuech and Hofman 2004; Keegan 2000; Pané 1999; Tabío and Rey 1966; Veloz Maggiolo 1972, 1993; Wilson 2007). Despite this, people, goods, and ideas were bound up in intensive and extensive networks of mobility and exchange, effectively bridging considerable diversity. This is a hallmark of Caribbean culture, if not many island cultures (Boomert and Bright 2007; Hofman et al. 2007).

In terms of belief and cosmology, sources of iconography on rock art, ceramics, bodily adornments, and social valuables 


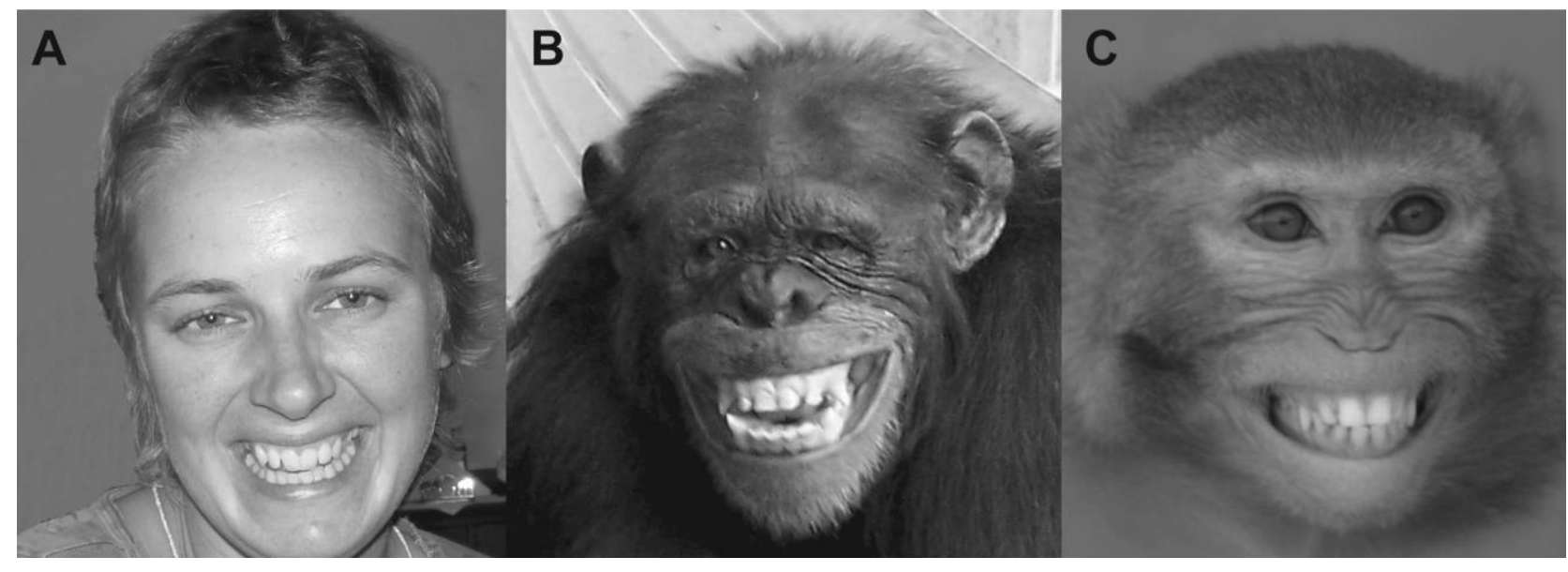

Figure 7. Bared-teeth display in human $(A)$, chimpanzee $(B)$, and rhesus macaque $(C)$. Photographs by Clare Caws (chimpanzee) and Lisa Parr (rhesus macaque).

and the report of Taíno religion written by Ramon Pané (fifteenth century) provide most of our current information. The evidence indicates that the Taíno inhabited an animistic world in which the natural world was participant and in which the dead, animals, plants, and rocks and the ancestors interacted with the human world. This is supplemented by what we know from present-day indigenous societies of the Amerindian tropical lowlands, who also share a complex animistic belief system (Boomert 2000). People, things, animals, and spirits are all social agents. The human world, a distinct and separable entity in Western discourse, is an enmeshed part of this animate world alive with complex relationships. These relationships needed to be managed and kept in balance.

Highlighting the heterogeneity of these societies, nevertheless culturally affiliated, and the complexities of their cosmology, in terms of the number and quality of relationships to be managed, raises some important questions in terms of community and intercommunity dynamics. It explains the importance of using clear communicative signals, such as the BTM, which acted as a sort of Taíno social grammar, allowing the indigenous peoples of the islands to engage with each other and facilitating interactions while retaining their differences (Rodríguez Ramos 2007:312-325).

Contact Period encounters provide us with a key example of this, one in which the brokering and affiliative strategies of the native inhabitants was diametrically opposed to the Christianizing and economic designs of European imperialism. The word "Taíno" means "I am good" or "I am noble," in other words, a ringing verbal statement of benign intent, a quality the indigenous people emphasized in meetings with the Spanish (Hulme 1986; Lovén 1935:502-503). The BTM can be considered the nonverbal equivalent of the word "Taíno." Assessing the iconographic innovation of the BTM

6. We are indebted to discussions with Roberto Valcárcel Rojas for this insightful observation. in a range of contexts on different artifacts serves to illustrate its particular social function.

\section{Quotidian Social Interaction}

The BTM would have been a common and familiar sight and would have served a function in many social arenas. Many personal items of dress, including shell decorations, were reportedly worn during public gatherings such as ceremonies in open plazas involving ritual song and dance (areitos) or public bathing. Such bodily adornments would have been markers of gender, status, and affiliation. Chroniclers report that men and women danced with bundles of small shells round their calves and arms on public occasions (Lovén 1935: 481). We know from archaeology that many of these shell bundles were incised with the BTM (Fundació Caixa de Girona 2006, pl. 65; Guarch Delmonte 1973, fig. 18), and these items are recovered from refuse deposits in habitation sites. Other items sporting the BTM and belonging to the settlement context would have been wood, stone, or cotton figures with shell teeth inlays and shell faces (guaizas). ${ }^{7}$ There is also some indication that the BTM may have been worn as a pendant on its own, removed and abstracted from its position as part of a face (Jardines and Calvera Rosés 1997; also Oliva spp. shells from the site of El Cabo, Dominican Republic). Moreover, items considered to be magico-religious in use, such as the vomiting spatulas, many of which incorporate the BTM, may also have been used in more routine purification (Casas

7. Where contextual information is known, teeth inlays and guaizas commonly occur within the domestic arena. Recently, shell teeth inlays have been recovered from excavation at the site of El Cabo, Dominican Republic, and 15 inlay pieces are known from the site of Chorro de Maíta, Cuba (Valcárcel Rojas 1999). Mol (2007:130-131) observes that all finds of guaízas with contextual information in the Greater Antilles come from habitation areas. 
1992:340). These items could be considered personal possessions and part of the household confection.

Fernández de Oviedo y Valdez (1851:125) was baffled that the Indians found such diabolical images so socially normal and common ("tan soçiable é comun") that they even kept them in their houses and sat on benches displaying them. The explanation of the BTM as a sign of affiliation and appeasement makes sense in terms of its incorporation in the Taíno household realm and clarifies Spanish confusion. We believe its use as a general social currency in day-to-day interactions-be it on public occasions, in small group interactions, or with spirit, animal, or human counterpartsformed part of an ethos of sociality and conviviality. This was consciously or unconsciously upheld in all social exchanges.

\section{Shamanic Practices}

It is interesting to note that many items with the BTM have been interpreted as shamanic paraphernalia (sniffing tubes and bowls, vomiting spatulas, cohoba stands) used for potentially more sequestered practices such as healing and ceremony. The shaman, or behique, of the early Spanish chronicles is a prominent figure in terms of his or her powers to heal and mediate the world between the living and the spirits and the dead (García Arévalo 2001; Pané 1999; Vega 1987). This early Contact information does not necessarily reflect the preColumbian situation, and we have no idea how many members of a particular society would have shamanic knowledge or what the nature of their status within society was. Nevertheless, in the Contact Period in Hispaniola, the role of the shaman could be characterized by communication: with individuals during healing and also as an intermediary between nonhuman and human worlds.

It is clear that healing was a principle task of a shaman and that this was a risky responsibility. Healing is an example of fraught social contact between individuals that has the potential to be ambiguous in terms of intentions. We know this because horrible punishments were meted out to shamans who were considered deceptive (Pané [1999:24-25] describes a case in which a shaman is put to death by being clubbed and having his eyes poked out and his testicles cut off). In this context, the BTM, which expresses the benevolent character (whether genuine or not) of the shaman's powers, would have been an important signal.

\section{Conclusion: The Bared-Teeth Motif as a Facilitator for Social Bonding}

It is our contention that the BTM served as a general affiliative and benevolent signal and thus had a communicative role in propagating social cohesion in the potentially dangerous arena of social exchanges. The BTM is the material corroboration of an active social strategy that engages and seeks proximity and accommodation, both with respect to numinous and human relationships and within and between communities, as the nonverbal equivalent of the concept "Taíno." This is in contrast to previous explanations that precluded an exploration of the social function of this expression because they were either interpreted as negative or not considered primarily as social signals. In addition, this interpretation may explain why or how the BTM was applicable to so many different contexts. We have demonstrated that the use of this motif was widespread and would have been a clearly understood, unambiguous, and commonly used signal. Similarly, the facial expression represented (smiling) is a universally understood, universally produced, and essential signal in human society.

\section{Acknowledgments}

This research was supported by grants from the Department of Psychology, University of Portsmouth, and the Caribbean Research Group, Faculty of Archaeology, Leiden University. We would like to thank the British Museum (and Colin McEwan) for access to its collection and Dirk Bakker for permission to reproduce his photographs. We would also like to thank the following people and groups for constructive input: Corinne Hofman; Menno Hoogland (and for permission to publish the El Cabo material, funded by the Netherlands Foundation for Scientific Research); Angus Mol; Roberto Valcárcel Rojas; Arie Boomert; Raymond Corbey; Jimmy Mans; Alistair Bright; Jorge Ulloa Hung; Lisa Parr (also for photographs); Stewart Watson; Daniel Haun; Adriana Churampi Ramírez; Peter Rivière; Helena Wright; Adam Jagich; Kathy MacDonald; the Centre for Human Ecology, Culture, and Communication (University of Portsmouth); and the Graduate Epistemology Seminar, Faculty of Archaeology, Leiden University.

\section{References Cited}

Alegría, R. E. 1981. La incrustación en la escultura aborigen antillana. In Proceedings of the Ninth International Congress for the Study of the Pre-Columbian Cultures of the Lesser Antilles, Santo Domingo, 1981. Pp. 325-347. Santo Domingo: Centre de Recherches Caraïbes, Université de Montréal.

Arrom, J. J. 1989. Mitología y artes prehispánicas de las Antillas. 2nd edition. México D.F.: Siglo Ventiuno Editores.

Boomert, A. 2000. Trinidad, Tobago and the lower Orinoco interaction sphere: an archaeological/ethnohistorical study. Alkmaar, Netherlands: Cairi.

Boomert, A., and A. J. Bright. 2007. Island archaeology: in search of a new horizon. Island Studies Journal 2:3-26.

Cassá, R. 1974. Los Tainos de la Española. Santo Domingo: Universidad Autónoma de Santo Domingo.

Curet, L. A. 2003. Issues on the diversity and emergence of middlerange societies of the ancient Caribbean: a critique. Journal of Archaeological Research 11:1-42.

-2005. Caribbean paleodemography: population, culture history, and sociopolitical processes in ancient Puerto Rico. Tuscaloosa: University of Alabama Press.

Dacal Moure, R., and M. Rivero de la Calle. 1996. Art and archaeology of pre-Columbian Cuba. Pittsburgh: University of Pittsburgh Press.

Deagan, K. A. 1988. The archaeology of the Spanish Contact Period in the Caribbean. Journal of World Prehistory 2:187-233. 
De Hostos, A. 1923. Anthropomorphic carvings from the Greater Antilles. American Anthropologist, n.s., 25:525-558.

De las Casas, B. 1992. Apologética historia sumaria de las Indias. Madrid: Alianza.

Delpuech, A., and C. L. Hofman, eds. 2004. Late Ceramic Age societies in the eastern Caribbean. BAR International Series. Oxford: Archaeopress.

de Waal, F. B. M., and L. Luttrell. 1985. The formal hierarchy of rhesus monkeys: an investigation of the bared teeth display. American Journal of Primatology 9:73-85.

Ekman, P., W. V. Friesen, and J. C. Hager. 2002. Facial action coding system. Salt Lake City, UT: Research Nexus.

Fernández de Oviedo y Valdez, G. 1851. Historia general y natural de las Indias, islas y tierra-firme del mar océan, vol. 1. Madrid: La Reál Academia de la Historia.

Fridlund, A. J. 1994. Human facial expression: an evolutionary view. London: Academic Press.

Frijda, N. H. 2009. On the nature and function of pleasure. In Pleasures of the brain: the neural bases of sensory rewards. K. S. Berridge and M. L. Kringelbach, eds. Pp. 99-112. Oxford: Oxford University Press.

Fundació Caixa de Girona, ed. 2006. Colom i els Taïnos. Barcelona: Fundació Caixa de Girona.

Fundación Centro Cultural Altos de Chavón, ed. 1992. Museo Arqueoloógico Regional: Cataálogo conmemorativo $V$ centenario: 1492-1992. La Romana: Fundación Centro Cultural Altos de Chavoón.

García Arévalo, M. A. 1997. The bat and the owl: nocturnal images of death. In Taino: Pre-Columbian art and culture from the Caribbean. F. Bercht, E. Brodsky, J. A. Farmer, and D. Taylor, eds. Pp. 112-123. New York: Monacelli/El Museo del Barrio.

- 2001. El ayuno del behique y el simbolismo del esqueleto. In Proceedings of the XIX International Congress for Caribbean Archaeology, Aruba, 2001. Pp. 56-69. Aruba: Museo Arqueológico Aruba.

Guarch Delmonte, J. M. 1973. El ajuar no-ceramico de los Taínos de $C u b a$, vol. 3. Serie Arqueológica. La Habana: Academia de Cinecias de Cuba, Instituto de Arqueología.

Guarch Rodríguez, J. J., and L. de Rosario Pérez Iglesias. 1994. Arte Rupestre: Petroglyphos Cubanos. Holguín: Ediciones Holguín.

Gutiérrez Calvache, D. A. 2002. Sobre el simbolismo y la funcionalidad del número en el arte rupestre de la Cueva de los Petroglifos. El Caribe Arqueológico 6:23-34.

Herrera Fritot, R., and C. L. Youmans. 1946. La Caleta: Joya arqueológica Antillana: exploración y estudio de un rico yacimiento indígena Dominicano, y comparación de los ejemplaros con los de Cuba y otros lugares. La Habana.

Hofman, C. L., A. J. Bright, A. Boomert, and S. Knippenberg. 2007. Island rhythms: the web of social relationships and interaction networks in the Lesser Antillean archipelago between 400 B.C. and A.D. 1492. Latin American Antiquity 18:243-268.

Hofman, C. L., A. J. Bright, M. L. P. Hoogland, and W. F. Keegan. 2008. Attractive ideas, desirable goods: examining the Late Ceramic Age relationships between Greater and Lesser Antillean societies. Journal of Island and Coastal Archaeology 3:17-34.

Hulme, P. 1986. Colonial encounters: Europe and the native Caribbean, 1492-1797. London: Methuen.

Jardines, M. J., and J. Calvera Rosés. 1997. Estudio técnico-estilístico de objetos de carácter superestructural de los grupos aborígenes agroceramistas de las Antillas. El Caribe Arqueológico 2:50-63.

Keegan, W. F. 2000. West Indian archaeology. 3. Ceramic Age. Journal of Archaeological Research 8:135-167.

Kerchache, J., ed. 1994. L'Art des sculpteurs Tainos: chefs-d'oeuvre des Grandes Antilles precolombiennes. Paris: Paris-Musées.
Krieger, H. W. 1931. Aboriginal Indian pottery of the Dominican Republic. Washington, DC: Smithsonian Institution.

Lee, J. W. 2006. The petroglyphs of Jamaica. In The earliest inhabitants: the dynamics of the Jamaican Taino. L.-G. Atkinson, ed. Pp. 177-186. Kingston: University of the West Indies Press.

Lovén, S. 1935. Origins of the Tainan culture, West Indies. 2nd edition. Göteburg: Elander.

Mehu, M., K. Grammer, and R. I. M. Dunbar. 2007. Smiles when sharing. Evolution and Human Behavior 28:415-422.

Mol, A. A. A. 2007. Costly giving, giving guaizas: toward an organic model of the exchange of social valuables in the Late Ceramic Age Caribbean. MP thesis, Leiden University, Leiden.

Pané, R. 1999. An account of the antiquities of the Indians. Durham, NC: Duke University Press.

Parr, L. A., M. Cohen, and F. B. M. de Waal. 2005. Influence of social context on the use of blended and graded facial displays in chimpanzees. International Journal of Primatology 26:73-103.

Preuschoft, S. 1995. "Laughter" and "smiling" in macaques: an evolutionary perspective. PhD dissertation, University of Utrecht, Utrecht.

Rabasa, J. 1993. Inventing America: Spanish historiography and the formation of Eurocentrism. Norman: University of Oklahoma Press.

Rives Pantoja, A. 1991. "Dentaduras de ídolo" (Asiento Cantabria, Cienfuegos): ejemplo de métodos de procesamiento computadorizado y de cluster analysis aplicados a la arqueología de Cuba. In Arqueología de Cuba y de atros áreas Antillanas. J. M. Guarch Delmonte, ed. La Habana: Editorial Academia.

Rodríguez Ramos, R. 2007. Puerto Rican precolonial history etched in stone. $\mathrm{PhD}$ dissertation, University of Florida, Gainesville.

Roe, P. G. 1997. Just wasting away: Taíno shamanism and concepts of fertility. In Taino: pre-Columbian art and culture from the Caribbean. F. Bercht, E. Brodsky, J. A. Farmer, and D. Taylor, eds. Pp. 124-157. New York: Monacelli.

Silk, J. B. 2000. The function of peaceful post-conflict interactions: an alternate view. In Natural conflict resolution. F. Aureli and F. B. M. de Waal. Pp. 179-181. Berkeley: University of California Press.

Tabío, E. E., and E. Rey. 1966. Prehistoria de Cuba. La Habana: Departamento de Antropología, Academia de Ciencias de Cuba.

Valcárcel Rojas, R. 1999. Banes precolombino: Jerarquía y sociedad. El Caribe Arqueológico 3:84-94.

2000. Seres de barro: un espacio simbólico feminino. El Caribe Arqueológico 4:20-34.

van Hooff, J. A. R. A. M. 1972. A comparative approach to the phylogeny of laughter and smiling. In Non-verbal communication. R. A. Hinde, ed. Pp. 209-240. Cambridge: Cambridge University Press.

Vega, B. 1987. Santos, shamanes y zemies. Publicaciones de la Fundación Cultural Dominicana. Santo Domingo: Fundación Cultural Dominicana.

Veloz Maggiolo, M. 1972. Arqueología prehistorica de Santo Domingo. Singapore: McGraw-Hill Far Eastern.

- 1993. La Isla de Santo Domingo antes de Colón. Santo Domingo: Banco Central de la República Dominicana.

Waller, B. M., K. A. Bard, S. J. Vick, and M. C. Smith Pasqualini. 2007. Perceived differences between chimpanzee and human facial expressions are related to emotional interpretation. Journal of Comparative Psychology 121(4):398-404.

Waller, B. M., and R. I. M. Dunbar. 2005. Differential behavioural effects of silent bared teeth display and relaxed open mouth display in chimpanzees (Pan troglodytes). Ethology 111:129-142.

Waller, B. M., S. J. Vick, L. A. Parr, and K. A. Bard. 2006. Intramuscular stimulation of facial muscles in humans and chimpanzees: Duchenne revisited. Emotion 6:367-382.

Wilson, S. M. 2007. The archaeology of the Caribbean. Cambridge World Archaeology. New York: Cambridge University Press. 